\title{
ПОВТОР ЯК ХУДОЖНІЙ ЗАСІБ В УКРАÏНСЬКІЙ ЛІТЕРАТУРНІЙ КАЗЦІ ХІХ СТОЛІТТЯ
}

Крашеніннікова Т. В. Повтор як художній засіб в українській літературній казці XIX століття.

У статті розглянуто повтор як художній засіб. Узагальнено наукові дослідження 3 цього питання. Звернуто увагу на класифікацію повторів в українському мовознавстві та подано види повторів у літературних казках. Наукову цінність становлять приклади, що підтверджують авторську індивідуальність на використання повторів у текстах на один сюжет.

Ключові слова: повтор, види повторів, літературна казка.

Крашенинникова Т. В. Повтор как художественный приём в украинской литературной сказке XIX века.

В статье рассмотрено повтор как художественный приём. Обобщено научные исследования по этому вопросу. Обращено внимание на классификацию повторов в украинском языкознании и подано виды повторов в литературных сказках. Научную ценность имеют примеры, которые подтверждают авторскую индивидуальность при использовании повторов в текстах на один сюжет.

Ключевые слова: повтор, виды повторов, литературная сказка. century.

Krasheninnikova T. V. Repetition as artistic approach in Ukrainian fairy-tale of the $19^{\text {th }}$

At the present article the repetition was studied. The scientific studies were summarized. The classification of repetitions in Ukrainian linguistics was paid attention to. The types of repetitions in Ukrainian literary tales were presented as well. The scientific value is devoted to examples, author's individual approach in using repetitions in texts of one plot.

Key words: repetitions, types of repetitions, literary fairy-tale.

В українському мовознавстві повтор досліджували О. Потебня (головне та творче завдання повтору полягає не в нагромадженні елементів змісту, а в художній їх організації) [6, с. 552], І. Білодід (основна стилістична функція повтору - це художнє увиразнення мови, зміцнення іiі експресивно-зображальних властивостей) [9]. В. Суханова дотримується поглядів І. Білодіда [8, с. 63], А. Коваль розглядає повтор як стилістичну фігуру, що утворюється через нагромадження певних мовних елементів у межах одного висловлення; виділяє синонімічні та парні повтори [3], О. Тараненко досліджує класифікацію повторів [10, с. 507-508], С. Срмоленко, I. Ковтунова, К. Кукушкіна, В. Чабаненко, І. Чернухіна вивчають повтор як синтаксичний засіб, а Л. Пришляк визначає його як синтаксичну конструкцію з повторенням елементів семантичної структури речення або цілого речення з тотожним, близьким чи відмінним лексикосемантичним наповненням зі збереженням або зміною позиції відносно інших елементів тексту [7, с. 5]. I. Кочан розглядає повтор як багаторазове відтворення різних лінгвістичних одиниць: фонем, морфем, лексем, слів, словосполучень, речень [4, с. 37]. 
Повтор у казкових текстах був об'єктом вивчення у працях Т. Жук (лексичний та синтаксичний повтор в українських народних казках) $[1$, c. 5], В. Масальського (ритмічні повтори в казці «Хо» М. Коцюбинського) [5], Я. Закревської (повтори в казках I. Франка) [2, с. 256-269].

Метою статті є дослідження особливостей повтору як художнього засобу в літературній казці ХІХ століття.

В українській мовознавчій науці активно аналізується використання повторів у художній літературі. Виділяють такі їх види: звукові, морфемні, лексичні (синонімічні, антонімічні, тотожні, парні), синтаксичні (сполучникові, безсполучникові), композиційні (анафора, епіфора, багатосполучниковість) та номінативно-експресивні.

Дотримуючись класифікацій повторів О. Тараненка та I. Кочан, виділяємо такі повтори на мовному рівні: морфемні, граматичні (іменникові, прикметникові, дієслівні, займенникові, прислівникові), синтаксичні та композиційні, зараховуючи багатосполучниковість до синтаксичних повторів, а не до композиційних, як це заявлено в деяких наукових працях.

Повтор як морфемний засіб зафіксований переважно: 1) у спільнокореневих дієсловах: Ще більш виростав той хлопчик, то він кращав та лучав, і оче він pic-pic $і$ виріс $(1$, с. 5); 2) прикметниках: Був собі раз у Галичині староста, та й острий-преострий! (20, с. 231); 3) одночасно в кількох частинах мови: I багато, багато ще дечого додавало смутку смутному чоловікові. Смутний чоловік те бачив $і$ щее дужче смутився (10, с. 203); 4) в однокореневих словах, що вирізняються суфіксами: Любий, любенький, любесечкий братику! (1, с. 65).

Повтор як граматичний засіб письменники використовували задля відображення хвилюючих моментів у житті людини, її емоційного стану і може бути виражений у казкових текстах іменником, що підкреслює: 1) тривалість природного явища: Ні теплого проміння, ні гарної квітки, ні веселої пташки, одно тобі - дощ, дощ, дощ, дрібний, густий, холодний (3, с. 100); 2) велику кількість предметів природи: Веселе літо настає, в гаях снують пташки, скрізь визирають із трави квітки, квітки й квітки (2, с. 13); 3) наявність міфічних істот: Наговорили їи нашибоваті баби про якихось мавок, а вона раз у раз про них, $і$ в сні лише мавки та мавки! $(18$, c. 257).

Прикметникові повтори у літературних казках передають душевний стан персонажів. Вони можуть бути двокомпонентні: Бідна, бідна Домаха, як згадаю я про неї, неначе й тепер бачу, як вона було сидить долі та співа ию пісню (5, с. 218), та трикомпонентні: Гіркий, гіркий, гіркий такий дуже! (1, с. 110), Бідна, бідна, бідна! - приговорює він. - На, моя маленька, на, на, на! (19, с. 396).

Серед займенникових повторів нашу увагу привернули означальні двокомпонентні та багатокомпонентні варіанти передачі інформації. Вони 
є засобом підкреслення емоційного смислового моменту. Те саме слово, повторюючись у різних контекстах, набуває кожного разу іншого відтінку значення; при цьому основне значення слова увиразнюється, у слові начебто відроджується його емоційність, його драматична напруженість: Усе зеленіло, усе пахло, усе співало, усе щебетало, лиш одна стара качка ні співала та ні щебетала, бо сиділа собі на яйиях та й виводила молодi каченята (16, с. 218); та вказівні трикомпонентні: Смільчака такого, такого красеня, такого розумниці, як ией хлопчик удався, пошукати по цілім широкім і великім світі (1, с. 4).

Найбільш поширеним у казкових творах є повтор дієслів доконаного та недоконаного виду. Дієслова минулого часу можуть позначати: 1) процесуальну дію: Як пішов, так $i$ пішов (9, с. 219); 2) зорове та слухове сприйняття: Бачив, бачив, такого бачив! (9, с. 237), Галя слухала-слухаласлухала, й пізненько вони розсталися (1, с. 89); 3) процеси мислення: Думав, думав та й заснув: змучився по лісі блукати (11, с. 349); 4) внутрішній стан людини: Коли оце ж знов засумував Кармель. Засумував та й засумував (1, с. 14).

Дієслівні повторювальні поєднання фіксують: 1) довготривалість дії: Там же в замку ждали, ждали та і годі вже сказали, глядь, аж-ось Іван іде, в поводку ї̈ веде (7, с. 260), Ох, били ж мене; били, били, били, щяо ні сісти, ні лягти не можна (4, с. 172); 2) завершеність дії в минулому: $A$ Осел плив, плив, поки не доплив щасливо до берега (21, с. 79); 3) повтор предикативної синтаксеми: Мав, правда, свою муровану хату, мав кузню, мав город і поле, мав усе, що йому було потрібно, лиш тяжко було забути за свого добродія, короля Данила $(11$, с. 94).

Дієслова теперішнього часу при повторі теж передають: 1) тривалу або постійну дію: Волоче Яким та й волоче (11, с. 252); 2) дії, що збігаються з моментом мовлення: Вигадуйте, вигадуйте, то таки візьме вас Хо в торбу (14, с. 179), Знаю, знаю, не хвались! (7, с. 255), 3) дії, що $є$ властивостями особи: Ви помиляєтесь, $i$ він помиляється також (21, с. 171); 4) емоційний стан людини: А жінка сидить та плаче, плаче, щзо чоловік покинув! (9, с. 224). У казковому тексті поширені дієслівні повтори, які означають рух, переміщення сушею, по воді тощо: Їдуmb, їуть, врешті бачать - три дороги розійшлися (12, с. 312), От ідуть вони та ідуть і вже далеко одійшли од берега (8, с. 54), Пливуть вони, пливуть, ба вже Вовк $і$ Лисичка здорово поголодніли (21, с. 78).

У літературних казках письменники досить часто використовують дієслівні повтори у формі наказового способу: 1) 2 особи однини: $T u$, сестричко, не журись, не журись, веселенько усміхнись, усміхнись! (3, с. 243), Дівчина тобі руки й ноги зв'яже, - втікай сам! втікай! А мене приходь визволяти! Втікай! (1, с. 108); 2) 1 особи множини: Ходімо, то й xодімо (21, с. 77$)$. 
Поширеними є повтори, виражені формою майбутнього часу дієслів: 1) доконаного виду: Та було як почне, як почне кричать на вулиці, аж коло серия холоне $(5$, с. 217$)$; 2) недоконаного виду синтетичної форми: $A$ перепелиия: я заспіваю, я заспіваю, я заспіваю (11, с. 351), Ой, зможу, мамуню, зможу, не бійтеся, - говорить Гандзя, повеселівши (18, с. 253).

Для літературних казкових творів XIX століття характерні певні структурні особливості прислівникових повторів. Більш ніж дворазове повторення мовної одиниці називають терміном «мультиплікація». При наявності відповідної інтонації і контексту ці повтори можуть створювати враження пришвидшеного мовлення, навіть своєрідної скоромовки. Це яскраво виражено у творах Марка Вовчка: 1) двокомпонентні: Пізно! Пізно! (1, с. 28); 2) трикомпонентні: Дарма Галя насторожає ушко і довгодовго-довгенько слуха й прислуха - усе тихо й темно, - й, при слухаючи, Галя сама зітхає (1, с. 67); 3) чотирикомпонентні: Натомившись вже стояти, Галя сіла, та чобіт не зняла $і$ заснула в чоботях, прибираючись на другий день рано-рано-рано-ранесенько йти далеко-далеко-далеченько гуляти (1, с. 56).

Якісно-означальні прислівники в казках вказують: 1) на якісну ознаку дії, стану або на спосіб їх вияву у повній формі: Швидше, Добра Трояндо, швидше! - сказав Березень. - Швидше, моя люба дитино (1, с. 125), Та, замисливии отсе, скверно, скверно осміхнувся та до челяді й метнувся (7, с. 249), або короткій формі: Та скоріш, скоріш біжіте! (12, с. 318), ... щзо день в бога, щзо година у дні, Кармель усе смутніш та смутніш, а що за смуток такий, за ким $i$ за чим - ніхто того не знає $(1$, с. 5); 2) виражають міру або ступінь якості чи дії: Щуки лепські та меженні, трохи-трохи не саженні поміж ними були де (7, с. 243), Тричі сонечко ховалось, тричі, ясне, і вмивалось, ось зіходе учетверте, кінь біжить золотошерстий (7, с. 197).

За допомогою обставинних прислівників виражаються значення: 1) способу дії: Метелик летить все ближче, ближче до згубливого світла (13, с. 16), Натомившись вже стояти, Галя сіла, та чобіт не зняла $i$ заснула в чоботях, прибираючись на другий день рано-рано-раноранесенько йти далеко-далеко-далеченько гуляти (1, с. 56); 2) час дії: $O$, давно, давно-давненько! (1, с. 108), Довго та й довго ще Лис озирався; якби йому тоді гирю зітнути, мала б вона, як здається, шпуйнути просто між кури, та вже обізвався з серием Барсук (7, с. 300).

Письменники в казках як додаткові мовні засоби активно використовують службові частини мови (сполучник, частка). За допомогою такої стилістичної фігури, як полісиндетон, у казкових текстах досягається уповільнення розповіді, більше розчленування, а водночас посилення відчуття зв'язку між словами чи групами слів, з'єднаних сполучниками. Отже, зафіксовано поєднання єднальними сполучниками i, й однорідних членів речення: 1) виражених іменниками: Живо де все те й 
поділось - $\boldsymbol{i}$ свинота розлетілась, $\boldsymbol{i}$ змївни, $\boldsymbol{i}$ двірець, $\boldsymbol{i}$ лихий той ияар-отещь (7, с. 270); 2) виражених прикметниками: Вся розпатлана, $\boldsymbol{i}$ боса, $\boldsymbol{i}$ брудна, i кривоноса, в роті чорні зуби два, руки, мов та грязь, сідї, а голосить, мов сова (22, с. 231); 3) виражених дієсловами: Таки так $\boldsymbol{i}$ сиплють, так $\boldsymbol{i}$ сиплють! (4, с. 224). Повторювальний єднальний сполучник $н i . . . н i$ вжито в казках перед компонентами синтаксичних конструкцій: $A$ вона дивится на мене, ні слова не вимове, ні з міста не стане (5, 219), Ні теплого проміння, ні гарної квітки, ні веселої пташки, одно тобі - дощ, дощ, дощ, дрібний, густий, холодний (3, с. 100). Варіантом до зазначеного сполучника $€$ $a н i \ldots a н i$, який вживається в казкових текстах перед іменниками: Мені барон ані брат, ані сват (24, с. 294), Їдуть так не день, не три дні вже у саквах самі злидні, ані хліба ні крихтини, ані солі порошини! (7, с. 185), іноді в поєднанні з прийменником: Для такого старі роки стаються упирями, що не дають спати ані в ліжку, ані в труні по смерти (19, с. 70). Протиставний сполучник але в ролі частки підкреслює розгубленість мовця: Але... але... пане прокураторе, - пробулькотів він (21, с. 169). Розділові відношення в складносурядному реченні виражені сполучником чи то...чи: Чи то я краду, грабую, чи вбиваю, чи мордую, чи святе беру на cмix? (22, с. 375). Цей сполучник в українській мові вказує на чергування дій, фактів, подій, послідовну їх зміну, несумісність тощо.

Серед службових частин мови зафіксовано повтори часток нi, ось. Частка $н i$ вживається на початку речення для вираження заперечення співрозмовникові, для застереження від будь-якої дії: $\boldsymbol{H i}, \boldsymbol{\mu i}, я$ я тебе не пущу (20, с. 237). Вказівна частка ось 3 повторенням використовується при описах для зосередження уваги на певних фактах, на послідовність їх перебігу в часі: Силка ж з своӥми ось-ось набігає, наглую смерть йому все обіияе (7, с. 284).

В українських літературних казках повторювальну функцію виконують вигуки: 1) емоційні, що складаються 3 повторення голосного i

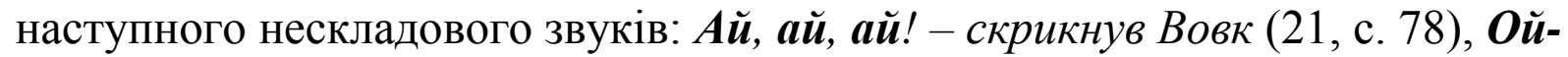
ой-ой, рятуй, Базильку, моя тітка вмре за хвильку! (22, с. 361); 2) вигуків, що виражають волевиявлення, спонукання до якоїсь дії: Ex, цить, старий, цить, ти перший туди ж, небораче! (23, с. 94), Но, но, чалий, но, швидше! (11, c. 252).

Поширеними є звуконаслідувальні слова. У казках вони відтворюють звукові сигнали тварин: Ме-ке-ке! (3, с. 252). Виступають у реченні переважно в ролі присудка: Голка все блись, блись (14, с. 469), «Вирвавсь! Вирвавсь!» - закричали люди, врозтіч поскакали, а Бурмило трух-трухmpyx! (22, c. 319).

У літературних казках XIX століття зафіксовано такі приклади синтаксичного повтору: 1) у формі звертання у препозиції з окличною інтонацією: Царице, царице! Тобі щось дома годиться: а що - мені не казати, а тобі треба о колисочку дбати (16, с. 158); 2) у формі звертання 
підсилений вигуком або звуконаслідувальним словом: а) у препозиції: Ой мамо-голубко, якби ви устали та дочку єдину тепер доглядали. Ой мамоголубко, почуйте, як плачу, хоч голос подайте, хоч хай вас побачу!.. (2, с. 168); б) у постпозиції: Гандзю, куку! Гандзю, куку! (18, с. 256); 3) поширене звертання, виражене поєднанням іменника із займенником: Степи мої, степи мой! (8, с. 54).

Композиційні повтори проявляються в казкових текстах у формі анафори (повторення того самого слова або кількох слів на початку кількох рядків у творі), яка відзначається великим багатством форми i задовольняє різноманітні стилістичні потреби художнього мовлення, вирізняється конкретними семантико-стилістичними відтінками вислову думки і почуття. Оскільки анафора виступає важливим засобом виразності в художньому тексті, а завдяки анафоричному повтору збільшується семантичний обсяг мовних одиниць, то вона служить основою різноманітних образних уявлень, підсилює емоційне сприйняття твору, зоктема й казкового: Вовк неситий, Вовк зажертий! Вовк усе є гідний смерти, Вовка бий, де лиш найдеш! - А що Вовк той голодує, жінку й діточок годує, Се байдуже всім! (22, с. 349), Хай їй цур, такій облозі! Хай ій цур, самій тій славі! Хай їй цур, тій перемозі!.. (12, с. 313).

Епіфора як стилістичний засіб, що полягає в повторенні однакових виразів, слів чи звукових сполучень у кінці віршованих рядків чи строф задля посилення виразності поетичної мови, у літературних казках $\epsilon$ непродуктивною і зафіксована лише у творах I. Франка: Ой $я$ собi садівник, садівник, в моїм саду лабазник, лабазник, між лабазом стежка бита; чи то хлопець, чи то дід моїм садом вільно йдіть, - від дівчат жадаю мита $(17$, с. 510).

Важливу композиційну роль у казках відіграє анепіфора (кільцевий повтор), яка використовується досить широко: $O$ горе, горе, $і$ паки реку: горе! (4, с. 143), Засідка, засідка! - пішов голос поміж звірами. - Обережно, бо засідка $(25$, с. 47$)$. Кільце строфи - це не обов'язково відокремлений, обрамлюючий рядок; він може бути синтаксичним складником речення: Сходіться, сходіть! Готовий обід, Ковбаска та й кишка, Ще й пражена гишка. Сходіться, сходіть! Готовий обід (15, с. 167).

Експресивна сила риторичного питання - ствердження, висловленого у формі питання - грунтується на властивій питальним реченням інтонації очікування відповіді, інтонації, покликаній привернути увагу читача: Смерть! Смерть! А щзо таке смерть? А де вона, та смерть? (3, с. 150).

Крім звичайних, художню палітру творів увиразнюють повтори синонімічні - нагнітання в тексті близькозначних слів або висловів. Такий повтор (синонімічний) дозволяе авторові повторювати думку, не повторюючи засобів іiі вираження, дає можливість змінювати форму висловлення думки, надаючи казкам емоційно-експресивного забарвлення: Та й став думати, думати та гадати, гадати та тужити (1, с. 15), Hy ж, кажи, нуж, кажи, говори! Може, треба до нори, до нори? (3, с. 219). 
Подібно до народних, у літературних казках, використовувався як стилістичний прийом повтор простих речень - розповідних, питальних, спонукальних, емоційно-окличних. Вони ілюструють переважно повторюваність певних подій, ситуацій, висловів та звуків: Он там... Он там... Он там... Ой, та й страшне ж! Ой, та й люте ж! (25, с. 78), Вовк в криниці! Вовк в криниці! За лошата і ягниці відплатім йому тепер! (22, с. 391), Що таке? Що таке? - скрикнув молодий козак, прокинувшись, може, трохи $i$ злякавщись, $i$ потрушуючи двері. Відчиніть-бо! Що таке? (1, с. 118).

Для народних казок характерними є повтори речень 3, 7 і 12 разів. У текстах авторських казок зафіксовані подібні повтори речень лише по 3 рази. Це елемент традиційної числової символіки як відголоску міфологічних уявлень про число як магічну величину, здатну впливати на здоров'я і життя людини або істоти: Кабане, Кабане, куди йдеш? (3 рази) $(25$, с. 24,25$)$, Смутний і невеселий сидів у світлиці на лавиі конотопський пан сотник Микита Уласович Забрьоха (3 рази) (4, с. 136, 141, 147).

Крім цього, письменники XIX століття ввели повтори речень у казках 2, 4, 5 та 6 разів. Цей прийом здебільшого допомагав їм підкреслити початок нового епізоду: Туре, Туре, Лихої натури, На Купала зі скали виходиш, Всякої паші много шкодиш. Але хто уб'є тя з лука, Буде жити, як той дука: Бо Дажбог є світа і сонечка пан, Платить за заслугу, що хоче хто сам (2 рази) [25, с. 479], Ой помалу-малу, вівчарику грай, Та не врази мого серденька вкрай... Мене сестри з світу згубили, Під кущем у лісі мене положили, У холодній ямі мене поховали, Ще й ногами землю зверху притоптали (2 рази; далі замість «вівчарику» слова батечку, матусенько, сестронько, вітре) [12, с. 17], Чому, чому не хочеш мене? (4 рази) $[16$, с. 230-231], ...ріпка сидить у землі, як пень (5 разів) [36, с. 2-4], Коржику, коржику! Я тебе з '̈м (6 разів) [19, с. 248].

Серед цих речень спостерігаємо й такі, які повторюються парами, тобто один вислів починає якусь дію, а інший завершує: Млинчик, млинчик, ну охочо! Змели мені, щзо я хочу. Змели мені зараз (то $і$ то). Млинчик, млинчик, ну же стій, Бо так хоче мельник твій! (15, с. 483).

На прикладі казки про козу-дерезу простежується авторський підхід до тексту Оленою Пчілкою та Дніпровою Чайною. Авторки доводять, що один i той же фрагмент сюжету можна подати по-різному, навіть використовуючи елементи стилю народної казки: «Кози мої любі, кози мої милі! Чи ви пили чи ви їли?» - А кози йому одказують: «Ні, дідусю, не пили, не їли! Бігли через місточок, Ухопили кленовий листочок, бігли через гребельку, ухопили водиці крапельку. Тільки пили і їли!» (4 рази) $(9$, с. 213), Козю моя люба! Козю моя мила! Чи пила ти, Чи ти їла? (3 рази) (3, с. 237, 238); Я, коза-дереза, півбока луплена, за три копи куплена, тупу-тупу ногами, сколю тебе рогами, лапками затопчу, ручками загребу, Хвостиком замету, гам тебе - з'ім! (4 рази) (9, с. 215), Я Коза-дереза, Півбока луплена, За три 
копи куплена, Тупу-тупу ногами, Сколю тебе рогами, Хвостиком замету, Ніжками затопчу, Тут тобі й смерть (3, с. 240, 242, 244, 248).

Отже, більшість повторів у казкових творах використано письменниками задля того, аби акцентувати увагу на душевному стані персонажа, указати на миттєвість або тривалість дії. Вони служать активним художнім засобом для вираження відповідного смислу. Крім того, повтори синтаксичних структур орнаментують прийоми зачину й кінця літературної казки.

\section{Література}

1. Жук Т. В. Лексичний та синтаксичний повтор в українській народній творчості (на матеріалі українських народних казок): автореферат...кандидата філол. наук : 10.02.01 - українська мова / Національний педагогічний університет ім. М. П. Драгоманова / Т. В. Жук. - К., 2005. -18 с.

2. Закревська Я. В. Із спостережень над мовою казок Івана Франк / Я. В. Закревська // Дослідження творчості Івана Франка. - К.: Вид-во АН УРСР, 1956. - С.256-269.

3. Коваль А. П. Практична стилістика сучасної української мови : [підручник] / А. П. Коваль. - К.: Вища школа, 1987. - 352 с.

4. Кочан I. М. Лінгвістичний аналіз тексту: [навч. посібн.] / I. М. Кочан. [2-ге вид., перероб. і доп.]. - К.: Знання, 2008. - 423 с.

5. Масальський В. І. Мова і стиль творів М. Коцюбинського / В. І. Масальський. - K., 1965.

6. Потебня А. А. Из записок по русской грамматике / А. А. Потебня. - М., 1958. - 320 с.

7. Пришляк Л. Б. Повтор як засіб експресивного синтаксису поетичного мовлення 60-х років XX століття: автореферат...кандидата філол. наук : 10.02.01 - українська мова / Донецький національний університет / Л. Б. Пришляк. - Донецьк, 2002. -20 с.

8. Суханова В. Ф. До питання про архітектоніку художнього твору / В. Ф. Суханов // Українське мовознавство, 1975. - Вип. 3. - С. 63-68.

9. Сучасна українська літературна мова. Стилістика / За заг. ред. акад. І. К. Білодіда. - К: Наукова думка, 1973. - 587 с.

10. Тараненко О. О. Повтор / О. О. Тараненко // Українська мова. Енциклопедія. К.: Укр. енциклопедія, 2000. - С.459.

\section{Джерела}

1. Вовчок Марко. Казки / Упоряд. і прим. В. О. Дорошкевича та I. Т. Купріянова - К.: Веселка, 1988. - 383 с.

2. Грінченко Б. Казки. - К., 1990.

3. Дніпрова Чайка. Проводи Сніговика-Снігуровича / Дніпрова Чайка. - К., 1993.

4. Квітка-Основ'яненко Г. Ф. Твори: у 2-х томах / Г. Ф. Квітка-Основ'яненко. Т.1. - К.: Дніпро, 1978.

5. Кернеренко Г. Правдива казка // Г. Кернеренко. Твори. Менти натхнення. Гуляйполе: Друкарня Н. Лібмана, 1910. - С.211-221.

6. Кобринська Н. Рожа // Н. Кобринська. Вибрані твори. - К., 1958. - С.225-235.

7. Манжура І. Вибрані твори / I. Манжура. - К., 1961.

8. Нечуй-Левицький І. Запорожці / I. Нечуй-Левицький. - К., 1994. 
9. Пчілка О. Годі, діточки, вам спать! / Олена Пчілка. - К.: Веселка, 1991.

10. Самійленко В. Казка про смутного чоловіка / В. Самійленко //

B. Самійленко. Твори. - К., 1990. - С.202-205.

11. Срібна книга казок. Українські літературні казки. - К., 1992.

12. Українка Леся. Давня казка // Леся Українка. Твори: у 2-х томах. - Т.1. - К.: Наукова думка, 1986. - С.301-322.

13. Українка Леся. Метелик // Леся Українка. Зібрання творів: у 12-ти томах. T. 7. - K., 1976.

14. Українська літературна казка / Упор.-ред. В. Полковенко. - К., 2001.

15. Федькович Ю. Бідолашко / Ю. Федькович // Ю. Федькович. На день добрий. - К., 1969.

16. Федькович Ю. Твори: у 2-х томах / Ю. Федькович. - К., 1960. - Т.2.

17. Франко I. Гримить / І. Франко. - К.: Радянська школа, 1986.

18. Франко I. Зібрання творів: у 20-ти томах / I. Франко. - Т.1. - К., 1955.

19. Франко I. Зібрання творів: у 20-ти томах / I. Франко. - Т.2. - К., 1950.

20. Франко І. Зібрання творів: у 20-ти томах / І. Франко. - Т.3. - К. 1950.

21. Франко I. Зібрання творів: у 20-ти томах / I. Франко. - Т.4. - К., 1951.

22. Франко I. Зібрання творів: у 20-ти томах / I. Франко. - Т.12. - К., 1953.

23. Франко I. Зібрання творів: у 20-ти томах / І. Франко. - Т.13. - К., 1954.

24. Франко І. Зібрання творів: у 50-ти томах / І. Франко. - Т.18. - К., 1978.

25. Франко І. Коли ще звірі говорили/ І. Франко. - К., 1976.

26. Франко I. Ріпка / I. Франко // Дивосвіт. - 1997. - №9-10. - С.2-4.

Стаття надійшла до редакиї 21.10.2010 p. 